\title{
COMMISSIONS OF INQUIRY AS A RESPONSE TO CRISIS: THE ROLE OF THE JALI COMMISSION IN CREATING PUBLIC AWARENESS OF CORRUPTION (PART 2)
}

\author{
Stephen Allister Peté \\ BA LLB LLM M Phil PhD \\ Associate Professor of Law, School of Law \\ University of KwaZulu-Natal
}

\begin{abstract}
SUMMARY
When the government of a liberal constitutional democracy is confronted by some or other existential crisis that threatens a major institution of state or the very foundations of the democracy itself, it will often appoint a high-level judicial commission of inquiry as part of its response to the crisis. South Africa is no exception to this tendency, as is evidenced in recent years by the appointment of no fewer than four such commissions in response to a series of crises related to ongoing corruption within state institutions commonly referred to by ordinary South Africans as "state capture". This has raised questions as to the alleged benefits of such commissions when viewed in relation to their considerable costs. This article seeks to contribute to this general debate by focusing on one of the purported benefits of such commissions that may be somewhat under appreciated. This is the creation of public awareness, during the life of the commission itself, about the nature and extent of the particular grave threat that confronts the society in question. It is contended that, mediated by a free and vibrant press, the public narrative that emerges during the operation of a commission of inquiry may serve to make a liberal democratic society more resilient in the face of threats to that society's continued existence. This article seeks to support this contention by focusing on an important precursor to the more recent commissions of inquiry on corruption in South Africa - that is, the Jali Commission of Inquiry into corruption within the South African penal system, which sat in the early years of the new millennium. By analysing the many articles and reports that appeared in a range of South African newspapers during the initial hearings of the Jali Commission, this article documents the emergence of an important public narrative on corruption within South Africa's prisons, and reflects upon the ultimate significance. This article is divided into two parts: the first part deals with the initial hearings of the Jali
\end{abstract}


Commission in KwaZulu-Natal, and the second part with subsequent hearings in the Free State.

\section{$1 \quad$ INTRODUCTION}

At the time this article is being written - just over a quarter of a century since the end of the apartheid era - South Africans are seeking to come to terms with the fact that a number of key institutions of state, together with the economy of the entire country, have been brought to the brink of collapse by widespread and ongoing corruption during the post-liberation period. As was pointed out in the introduction to Part 1 of this article, a common response by governments of liberal constitutional democracies, when facing "existential" crises of this sort, is the appointment of one or more public judicial commission of inquiry. South Africa has followed this practice: four high-profile judicial commissions of inquiry were appointed by President Cyril Ramaphosa, shortly after he assumed power in 2018, to investigate various aspects of corruption in the country. This has led to questions as to whether the alleged benefits of such commissions of inquiry are worth their considerable costs. ${ }^{1}$

This article seeks to contribute to this debate by focusing on one potential benefit of such commissions, which, although obvious, may be somewhat under appreciated. This is the benefit of public awareness about the nature and extent of the particular threat being investigated that is created during the life of a commission of inquiry. This is distinct from other potential benefits related to the official report that is published at the end of each commission of inquiry. In order to illustrate the manner in which such public awareness is created, as well as its potential role in protecting constitutional democracy, this article is focused on the considerable publicity generated in the South African press on the initial hearings of one of the first important public judicial commissions of inquiry into corruption during the postapartheid era - namely, the Jali Commission of Inquiry into corruption within the South African penal system, which sat between 2000 and 2005. Whereas Part 1 of this article examined the many reports and articles that appeared in a range of national newspapers about the hearings of the Commission held in 2002 in KwaZulu-Natal, Part 2 focuses on the hearings that were held in the Free State later in the same year. This both confirms and adds nuance to the themes that emerged in Part 1, as well as adding a further chapter to what has been referred to in Part 1 as the "living history" of corruption within the South African penal system.

\section{COMMISSIONS OF INQUIRY AND THE PRESS IN SOUTH AFRICA - A BRIEF HISTORICAL NOTE}

Part 1 of this article provided an overview of certain of the more common arguments put forward by scholars for and against the appointment of public

1 See the introduction to Part 1 of this article in 2020 41(4) Obiter 902-906. 
commissions of inquiry in response to a national crisis. In particular, it discussed the important role of such commissions - in conjunction with a free press - in informing and educating the public about the nature and extent of the threat being faced. These arguments need not be repeated in detail here. At this point, it is worth noting, however, that press reporting on the hearings of the Jali Commission of Inquiry did not mark the first time that the South African press played an important role in revealing the threat posed by widespread corruption to the country in general and the penal system in particular.

South Africa's free press has clearly played a vital role in revealing the nature and extent of corrupt activities that have afflicted various institutions within the country over many years. There is strong historical evidence indicating that the South African media in general, and the press in particular, have made good use of the proceedings and processes surrounding commissions and committees of inquiry, including their published reports, in order to publicise facts about the country's prison system that would otherwise not have become known to the broader South African public. Far from serving to bury controversial matters within a set of legal rules, regulations and procedures, the appointment of such inquiries often gave those in the South African media - the "liberal" press in particular - the gap they needed to forcefully and regularly remind their viewers and readers of what was really happening in the prisons.

The above was true even during the apartheid period. Just one example drawn from this period is the extensive press coverage given to the shocking overcrowding that existed in South African prisons in the early 1980s. This coverage was thanks to a public commission of inquiry into the structure and functioning of South Africa's courts, known as the Hoexter Commission. ${ }^{2}$ At this particularly repressive time, the South African media were faced with legislative provisions that severely limited what they could publish about conditions in the country's prisons. ${ }^{3}$ However, because Judge Hoexter ruled that evidence before his commission had to be given in public, the press was able to "lift the veil" on the appalling conditions in the country's massively overcrowded prisons and lambast the apartheid regime. ${ }^{4}$ This was significant in the context of the wider ideological battle that was taking place within the apartheid regime at the time, as expressed here:

The Hoexter Commission of Enquiry was appointed on 29 November 1980.

$3 \quad S 44(1)(f)$ of the Prisons Act 8 of 1959 stated as follows: "Any person who publishes or causes to be published in any manner whatsoever any false information concerning the behaviour or experience in prison of any prisoner or ex-prisoner or concerning the administration of any prison, knowing the same to be false, or without taking reasonable steps to verify such information (the onus of proving that reasonable steps were taken to verify such information being upon the accused) shall be guilty of an offence and liable on conviction to a fine not exceeding two thousand rand or, in default of payment, to imprisonment for a period of not exceeding two years or to such imprisonment without the option of a fine or to both such fine and such imprisonment."

4 See, in general, Peté "Holding Up a Mirror to Apartheid South Africa: Public Discourse on the Issue of Overcrowding in South African Prisons 1980 to 1984 - Part One" 2014 35(3) Obiter 485-505. 
"[D]espite the legislative restrictions which were in place during the early 1980 s preventing open reporting about conditions in South African prisons, a close examination of the public discourse during this period reveals a rich series of debates on the issue of chronic overcrowding. Of particular interest is the fact that these debates were inextricably linked to debates on the viability of the apartheid system itself, in particular the measures of social control which had been put in place by the apartheid regime. It is submitted that these debates acted as a mirror to ordinary South Africans, particularly white middle class South Africans who were the beneficiaries of the apartheid system, revealing to them the moral bankruptcy of the system, as well as the fact that it was impractical and untenable in the medium to long term." 5

Another example of how the South African media made "good use" of public inquiries into prison conditions during the apartheid period was the release of the report of the "Van Dam Committee", which investigated conditions at the notorious Barberton prison complex in late 1983 and early 1984. As in the case of the Hoexter Commission discussed above, the South African "liberal press" had a field day with the damning findings of this particular committee of inquiry, and were able to reveal something of the sickening abuse and mismanagement that afflicted the apartheid penal system. ${ }^{6}$ Once again, the revelations served at a wider ideological level as yet another chink in the armour of the apartheid system.

Further examples of the general point made above could no doubt be given, but this article must now return to its specific focus on the Jali Commission and, in particular, the hearings held in the Free State.

\section{PUBLIC DISCOURSE SURROUNDING THE HEARINGS OF THE JALI COMMISSION IN THE FREE STATE}

This section of the article traces the public discourse surrounding the revelations contained in evidence given before the Jali Commission of Inquiry during its hearings in the Free State. It also traces details of a public furore surrounding the airing of a video on national television, showing prisoners and warders at Bloemfontein's Grootvlei Prison engaged in a range of corrupt activities. Although the details of the corruption in the Free State differ from those in KwaZulu-Natal, it is clear that the shock and anger felt by the South African public at the time of the revelations remained the same. It is also clear that the virus of corruption had infected large sections of the South African penal system at this time.

\section{Seeing is believing: video evidence of corruption at Bloemfontein's Grootvlei Prison}

It is especially useful to examine corruption at Bloemfontein's Grootvlei Prison through the lens of the South African public media - since the usual

5 Peté 2014 Obiter 485-505.

6 For a detailed analysis, see Peté "Apartheid's Alcatraz: The Barberton Prison Complex During the Early 1980s - Part Two" 2015 PER 305-330. 
media frenzy that accompanied the hearings of the Commission was stoked by a "media event" that had been initiated by the prisoners themselves. This "media event" was the airing of a video that had been filmed in secret inside the prison in question, by four inmates. These inmates (Gayton McKenzie, 28, Moosa Mia, 30, Petrus Sekutoane, 52, and Samuel Grobbelaar, 43) became known as the "Grootvlei Four". When the video was aired in June 2002 on national television in the programme Special Assignment, South Africans exploded in outrage at what the video revealed of the widespread corruption inside Grootvlei.

The airing of the video gave rise to a wave of reports in all major South African newspapers. When the story broke in the national press, the "Grootvlei Four" told the Sunday Times that they had paid R146 000 to make the video, which had taken five months to film. ${ }^{7}$ Five mini-cameras and microphones were set up in a cell, the kitchen, two tuckshops and the prison petrol station. The camera in the cell was hidden in a box of tea in order to evade detection in the event of a search by prison officials. McKenzie, who approached two friends for the money to hire the necessary equipment, masterminded the operation. Mia and Sekutoane helped to entrap certain corrupt warders, while Grobbelaar was responsible for smuggling the equipment into the prison, and for editing the video. The scenes were edited together by taping from one video machine to another.

The head of the prison was only informed about the sting operation after the four managed to film Mia (serving 30 years for two murders) buying a pistol and a bullet from a warder for R6 000 . Once the video was complete, one copy was handed to the head of the Grootvlei Prison, Tatolo "Champ" Setlai, and another to lawyer, Nico Naude, for safekeeping. According to the four prisoners, their motives for filming the video were to: help break the criminal rings that operated in the prisons; force reform of the prison system; show the public how their taxes were being misspent; and secure a two-year reduction in their sentences, which they believed was given to all prisoners who exposed corruption. McKenzie told the Sunday Times that he was fed up with corrupt warders using prisoners as their "slaves" for everything from polishing their shoes to performing sex acts, and said:

"You get paedophile prison warders who have sex with juvenile prisoners. I call it consensual rape. The Roman Catholic Church has now admitted that some priests molest boys but the Department of Correctional Services is afraid to come out in the open." 8

Sekutoane, who was shown on the video sodomising a 21-year-old prisoner, told the Sunday Times that he had only done so in order to trap the warder. The young man who was sodomised was allegedly paid R10 and some tobacco for his services, while the warder was paid R20 for arranging for Sekutoane to have sex with the young man. Sekutoane admitted that he had paid juvenile prisoners for sex many times, but claimed that he had stopped

7 (2002-06-23) Sunday Times 7. Although Grobbelaar later told Rapport that the filming had taken place between 15 March 2002 and 14 May 2002 - see (2002-06-23) Rapport 4.

8 (2002-06-23) Sunday Times 7. 
doing so some time previously. He stated that he had not wanted to be seen on television having sex with a man:

"I felt very bad about doing it because I've got a daughter who's going to see it."9

Grobbelaar told the Sunday Times that two attempts had been made to kill him after the video was shown on television. First, he was hit on the back of the head with a sock filled with steel and was knocked unconscious. The attack was allegedly carried out by another prisoner who had been hired by one of the warders incriminated in the video. While in hospital, a second attempt was allegedly made on his life. He claimed that one of the corrupt warders had provided a prisoner with poison with which to poison him (Grobbelaar) but that the attempt had been foiled when the prisoner with the poison had been intercepted before he could carry out the plan. Grobbelaar stated:

"We've encouraged so many prisoners to come out with the evidence. l've even spoken to some 14-year-olds who have been molested. l'd rather die in [this] prison than be moved." 10

In addition to the scenes referred to above - of warders selling a stolen pistol to Mia and a warder bringing a juvenile prisoner to Sekutoane for sex the video also contained other incriminating scenes, including warders buying frozen chickens that had been stolen from the prison kitchen; warders selling mandrax and dagga to prisoners; and warders fraternising and drinking brandy and Coke with prisoners. ${ }^{11}$ It was no wonder that the video was described in the press as "explosive". ${ }^{12}$

The South African press had a field day with the revelations - as well as the apparent failure of the Department of Correctional Services to deal promptly and decisively with the corrupt warders. Under the banner headline "Caught red-handed, still at large", The Star posed the following question in bold and enlarged type on its page one:

"Prison warders gave a loaded gun to hardened criminals so that they could use it to escape. They produced young boys for adult prisoners to have sex with. They traded in hard drugs with the prisoners. They were caught on camera committing these serious crimes. Their punishment? Suspension. We want to know: WHY HAVEN'T THEY BEEN ARRESTED."13

The page one article went on to claim that the office of the National Commissioner of Police, Jackie Selebi, was unable to explain why the police had not arrested the 22 warders shown in the video. A spokesperson for the Commissioner, Senior Superintendent Selby Bokaba, was quoted as saying:

"We are of the view that no one has laid a complaint or a charge, as we cannot act on a TV programme. If anyone comes forward to lay a charge, we

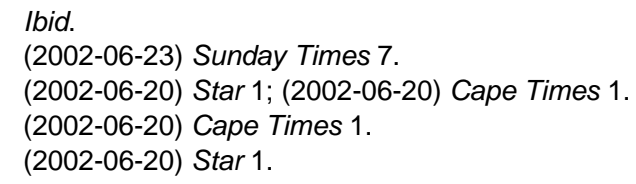


will act. Correctional Services has suspended the warders and we must also wait for the Jali commission to conclude its investigations."14

Statements such as that quoted above served to fuel the disappointment and anger felt by many South Africans at this time. The fact that the Department of Correctional Services had failed to take more decisive action in the wake of the exposé was met with outrage in the press. The responses of several national newspapers are worth quoting at some length, since their opinions provide a clear indication of the shock and disillusionment that resulted from the events at Grootvlei. The following are extracts from editorials dated 20 June 2002, in Business Day, The Citizen, The Pretoria News, and The Herald respectively:

"Sadly, instead of offering kudos to Setlai and the four prisoners who literally risked their lives to expose the unsavoury goings-on at the prison, the authorities have seemingly chosen to discourage whistle-blowing and to threaten Setlai with suspension for sanctioning the operation. Worse still, none of the implicated warders have been suspended. It beggars belief. And there are reports that one of the prisoners who recorded the video was severely assaulted and poisoned in an attempt to kill him." ${ }^{15}$

“Even if South Africans aren't surprised by the corruption at Grootvlei prison, the expose on Special Assignment is a shocking indictment of the Department of Correctional Services. If confirmation were needed, the country now knows that life behind bars can be quite comfortable for murderers and their ilk. They have access to firearms, drugs, alcohol and sex, with the active connivance of jail warders. What a splendid advertisement to promote the outlaw life. The nation can see crime does indeed pay, for some. Just as disturbing as the goings on was the attitude of the department. It was wrong that so many warders with known dubious records were allowed to continue their duties before being caught on camera. But it is absolutely scandalous that they're still on duty now, and the department displays virtually no interest in bringing them to book ... [W] hat we need is firm, decisive action. Kick out the rotten staff immediately, and tighten up. If the wavering Mti is not up to the job he too must go."16

"Sex, drugs, booze and rock ' $n$ roll - it's all been happening in Bloemfontein's Grootvlei Prison. Yet, National Correctional Services Commissioner Linda Mti appears to have missed the point completely. Reacting to the hair-raising video filmed in the prison showing warders selling prisoners alcohol, drugs, facilitating sexual services and even making available a loaded firearm, Mti's stupefying response was that his department was 'not in the business of making videos' and did not support the making of it. Good gracious! Does Mti believe that such goings-on in our jails - it is hardly likely Grootvlei is an isolated case - are better kept under wraps? ... Whatever action is necessary must be taken where needed to root out this cancer in our jails."17

"There can now be no doubt about why SA prison gates are about as secure as a well-oiled revolving door. An expose on corruption at Bloemfontein's Grootvlei prison, flighted by SATV's Special Assignment this week, revealed breathtaking corruption showing warders to be no more than messengers for inmates who have money for booze, drugs, sex and even a firearm. A video showing this has been in the hands of prison authorities for some time, but not

14 Ibid.

15 (2002-06-20) Business Day 15.

16 (2002-06-20) Citizen 16.

17 (2002-06-20) Pretoria News 11. 
one of the warders involved has been suspended. It can only be speculated that their roaring trade in vice, drugs and whatever else, continues to flourish ... When prisoners get worried about the level of corruption, it is time government sat up and took note. In case it doesn't know, it has egg on its face." 18

Seemingly bowing to public pressure, the Minister of Correctional Services, Ben Skosana, responded to reports that the head of the Grootvlei Prison, Tatolo Setlai, was to be suspended for allowing the filming of the video in his prison, by stating that he was opposed to any such suspension. He pointed out that, although procedures and regulations may have been abrogated, it would not be wise to suspend Setlai - because he had been a "facilitator for the greater good". He added that he would not encourage exposure of this sort, since it was not "helpful" to publicise information of this type without "putting it into perspective". The Minister also announced that the warders who appeared in the video would be suspended, and that the four prisoners who had filmed the video would be transferred to other prisons to ensure their safety. ${ }^{19}$

Civil society groups also began commenting in the press on the corruption at Grootvlei. For example, on 21 June 2002, the leader of the Southern Africa Methodist Church, Bishop Mvume Dandala, issued a statement in which he expressed his outrage at the criminal activities taking place in the prison:

"We are appalled that it took an illegal action to uncover the shocking malpractice of corruption, gangsterism and violence that is allegedly being freely perpetrated at the Grootvlei Prison. We unequivocally condemn the illegal activities highlighted in the video taken by inmates, desperate to bring justice to the system. Having to resort to this action also reveals an alarming lack of channels for complaints." 20

18 (2002-06-20) Herald 4. Editorials expressing grave concern over the events at Grootvlei continued to be published in South African newspapers for some days following the initial flood of reports. For example, in its editorial of 22 June 2002, the Natal Witness commented on the Grootvlei Prison video as follows: "While the evidence being put before the Jali Commission of murder and mayhem in the KwaZulu-Natal prisons services has been shocking enough, the video footage of goings-on in Bloemfontein's Grootvlei prison has provided positively astounding confirmation of what many outsiders have long suspected that the country's prisons are dens of unparalleled iniquity ... It goes beyond the levels of incompetence and corruption that have in recent years come to be regarded as normal in much of the public service. The public has been confronted with the terrifying reality that what goes on inside the prisons is the complete antithesis of what 'correctional service' is supposed to mean. It is all the more alarming, and all the more reprehensible, because these prison officers have been entrusted by society with the task of protecting the community by curbing crime. The individual offenders must now feel the full force of the law ... no doubt the reasons why things have come to this pass are many and complex, but poor management is certainly among them and there must be appropriate action at this level too. In fact, ministerial intervention is obviously overdue. The minister has reportedly commended the Grootvlei head for letting the video cameras into the prison, and rightly so. It is most unsatisfactory that this should be so, but (as with the filming of corruption in the post office a while back) it seems that only the public outrage sparked by graphic televised images has the force to galvanise officialdom into action" ((2002-06-22) Natal Witness 6). (2002-06-20) Cape Argus 2.

20 (2002-06-22) Saturday Star 2. Another body that issued a public statement around this time was the Law Society of South Africa. On 23 June 2002, the Law Society called for the immediate arrest and suspension of all the warders implicated in the video. A spokesman 


\section{The Commission hears evidence on corruption at Grootvlei Prison}

At the same time that the story of the Grootvlei video was raging in the nation's press, the Jali Commission was hearing evidence about the events depicted in the video. It was reported that warder A Tlakudi, who was shown on the Grootvlei video buying chicken and drinking brandy, told the Commission that he had bought the chicken to give to an inmate, Wilson Mohodi, who had not eaten all day, and had merely tasted the brandy to determine whether it was alcohol or tea. On 19 June 2002, Wilson Mohodi gave evidence before the Commission and claimed that Tlakudi had threatened that "a gun would be used" if he did not corroborate Tlakudi's story. ${ }^{21}$ Moosa Mia also gave evidence before the Commission on 19 June 2002. He stated that he would sell chickens stolen by a warder, with 70 per cent of the proceeds going to the warder and 30 per cent retained by him. He also stated that six warders often bought brandy from him and that they had accounts with him that were settled on the $16^{\text {th }}$ of each month, which was the day after they were paid. He told the Commission that a single tot sold for R15.22

Three days later, further explosive evidence, which was widely reported in the press, was presented to the Commission. Tatolo Setlai, the head of Grootvlei, told the Commission that the Commissioner for Correctional Services in the Free State, Willem Damons, had asked him to destroy the Grootvlei Prison tape. After he (Setlai) had refused to destroy the tape, Damons allegedly asked him to hand the tape to the National Intelligence Agency. Setlai had also refused to do this, since he suspected that the National Intelligence Agency would destroy the tape. Setlai told the Commission that he had received a letter linking his possible suspension to the video tape. Setlai was reported as having stated inter alia, as follows:

"During the apartheid era, if a prisoner was found with two grams of dagga it was like a terrorist action, it never happened. In those days prisoners made means themselves, but nowadays members are deeply involved in such activities. They [i.e. prison officials] take democracy as a laissez faire government. They think they can do as they wish and some of them, when they take prisoners rations, they say they are eating their taxes. It is as if some black members don't fear black management as much as they feared white management." 23

On the same day that Setlai was giving his evidence to the Commission, the "Grootvlei Four" launched an application in the Free State Provincial Division of the High Court in Bloemfontein to prevent their transfer to the Mangaung

for the Law Society, Vincent Saldanha, stated that there was enough evidence on the videotape, coupled with the affidavits, to ensure that immediate action was taken: "The police should consult with the National Director of Public Prosecutions and if they cannot (take action) hand it over to the Scorpions to investigate" ((2002-06-24) Diamond Fields Advertiser 2). (2002-06-20) Cape Times 1.

22 lbid.

23 (2002-06-22) Saturday Weekend Argus 5; see also (2002-06-23) Sunday Tribune 13. 
prison. ${ }^{24}$ The reason they gave for their application was that they feared their lives would be in danger in that prison.

Two days after the above events, an article in the Sunday Tribune asked a number of provocative questions of the role of Tatolo Setlai in the sting operation. In the first place, why did Setlai allegedly retain an illegally obtained firearm in his possession for just over a month without informing the police? Secondly, why did he not involve the police in setting a trap for the warders? Thirdly, was it legal and/or moral for Setlai to allow warders and prisoners to commit crimes in order to prove that corruption was rife in Grootvlei Prison? The writer of the article made this final point, as follows:

"Did the head of the prison allow drugs to be peddled inside his institution so that can (sic) prove a point? The prisoner who was filmed sodomising a youngster said he arranged the filming himself. Which begs the question, did the head of prison know and allow a juvenile prisoner to be taken from his section to a prison cell where he would be sodomised by an older inmate so that it can (sic) be proved that corruption happens?"25

Although Setlai's role was questioned by some, he seemed to have considerable support within the South African press. For example, on 23 June 2002, the Sowetan Sunday World editorialised, inter alia, as follows:

"One can understand the desperation of the prison head in colluding with prisoners to rid himself of corrupt officials. Commissioner Linda Mti's threatened action against Tatolo Setlai, Grootvlei Prison's chief, is reprehensible but not surprising. It is similar to Henry Blazer's treatment when he blew the whistle on deputy speaker Baleka Mbete-Kgositsile's instant driver's licence. He was hung out to dry. This is the typical knee-jerk reaction of bureaucrats who think they are impervious to public censure. We applaud the cabinet ministers' quick action on the matter. Ben Skosana, correctional services minister, has placed the prisoners under his protection and Penuell Maduna, justice minister, has pledged his support for Setlai."26

The City Press also voiced its support for Setlai, and called on the authorities not to suspend him:

"The suspension of Setlai, as suggested this week by Mti, would amount to punishing a whistle-blower while simultaneously protecting those who want to cover up corruption in the South African civil service, which is already rotten with corrupt elements ... We ... believe the suspension of Setlai would be a heavy blow for honesty and a betrayal of the many anti-corruption campaigners in this country. Mti must be stopped!"27

With public pressure building, a team of correctional services directors was dispatched to Bloemfontein on 22 June 2002 to lay departmental as well as criminal charges against all the prison officials at Grootvlei who were involved in the corruption scandal. ${ }^{28}$ In the face of all the negative media attention, Linda Mti began to engage in "damage control", claiming that his

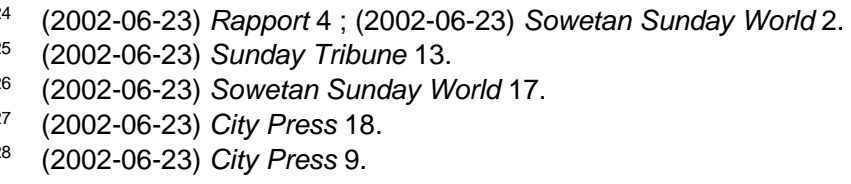


alleged call for Tatolo Setlai to be suspended had been quoted out of context. He defended his actions, as follows:

"First and foremost I commend and hail all efforts that anybody makes to expose prison corruption, whether it's committed by the warders or by the prisoners. But it is important not to be overzealous and compromise themselves and the law in the process of exposing the culprits. There are rules and regulations that cannot be ignored under any circumstances. We are a security entity and the rule of law is primary. Otherwise we will end up being a law unto ourselves ... How is it possible that hardcore criminals who are serving 102 years among themselves can produce such high-quality video material over three months without outside help? Overcrowded as our prisons are, officials are expected to uphold the rule of law at all times. That is why there is a thorough investigation on how this happened."29

The following day it was reported that Tatolo Setlai had received death threats as a result of his role in exposing corruption within Grootvlei Prison. Setlai believed he was being victimised by officials in the department. Inter alia, he stated:

"I do not regret helping those prisoners ... It is strange now that instead of the content being the subject of discussion, I am being questioned." 30

The Sowetan made the following telling comment on the infighting that was taking place between Setlai and his colleagues:

"Though Setlai has received high-level backing from the minister for his role in blowing the whistle, some of his colleagues in Correctional Services have not only questioned his motives for exposing the corruption, but are also baying for his blood ... The death threats on Setlai and other whistleblowers are likely to reopen the debate about the adequacy of the legal protection granted to those who expose corruption in the country." 31

The press continued to report on the high drama being played out at the hearings of the Jali Commission. On 25 June 2002, the "Grootvlei four" appeared before the Commission and claimed they had been roughed up and abused by the prison task force. ${ }^{32}$ One of them, Gayton McKenzie, told the Commission that he had often been sent, by warder KJ Mvubu, to buy meat that had been stolen from the prison kitchen. He told the Commission that since Mvubu had started working in the prison he had eaten more meat than any person who had been in prison for years. He also told the Commission that prisoners drank brandy in front of Mvubu without any action being taken. Moosa Mia (another of the "Grootvlei four") told the Commission that he regularly paid "toll fees" to warder Ranketse Sephaka for the warder to take him to other parts of the prison. The video showed Sephaka taking Mia to a cell so that he could buy dagga from Mr Petrus Sekutoane. Mia had paid R10 to Sephaka for taking him to the cell. At Mia's request, Sephaka carried the dagga for Mia by inserting it in the front of his

29 (2002-06-23) City Press 9. The article in City Press noted that Grootvlei Prison had been designed to accommodate 800 prisoners - but was forced to accommodate 1800 prisoners at the time the video was made.

30 (2002-06-24) Sowetan 1

31 lbid.

32 (2002-06-26) Star 2. 
pants. Mia also told the Commission that Sephaka had sold mandrax to him over a period of eight months. In return, Mia had regularly given Sephaka free meat. Mia further told the Commission that warder Tsietsi Mokhitli regularly borrowed money from him. He had lent amounts of R20 to R600 to Sephaka on approximately 12 occasions this year. ${ }^{33}$

Evidence that at least some concrete action had been taken against the warders suspected of corruption at the Grootvlei Prison emerged on 25 June 2002, when it was reported that 22 warders had been suspended and refused entry to the jail until investigations had been completed. Despite this, press reports indicated that the matter was still not being treated as seriously or urgently as was required. Of concern was that the Free State Police continued to claim they had no grounds on which to arrest any of the suspended warders..$^{34}$ Of further concern was that the delay on the part of the Department of Correctional Services in suspending the warders could have negatively affected the investigation into their alleged corrupt activities. The Sowetan complained as follows:

"We must ... register our concern that it had taken almost a week before the warders were barred from returning to duty ... We can only speculate on the impact this evident lack of urgency might have had on investigations. After all, prison authorities had argued the suspensions were necessary to ensure that no one interfered with the probe into allegations of corruption." 35

The Sowetan also expressed its concern that none of the warders had, as yet, been charged:

"Police have yet to arrest anyone in connection with the allegations. Suggestions by police that evidence at hand was insufficient to warrant any arrest is nothing but a cop-out." 36

\section{Public outrage over the Grootvlei Prison video continues to grow}

On 26 June 2002, it was reported that Tatolo Setlai, the head of Grootvlei Prison who had played a role in revealing the extensive corruption within the prison, had been informed that he was to be transferred to another post against his will. He told Volksblad that he was informed by his area head that he was being transferred to the provincial head office of correctional services in the Free State. He said that he was waiting for a letter confirming this, and that it would break his heart to be transferred. ${ }^{37}$ The Department of Correctional Services denied that it intended to transfer Setlai, stating that

\footnotetext{
(2002-06-26) Volksblad 2.

34 (2002-06-25) Sowetan 3. It took another four days before any criminal charges were laid against the warders. On 29 June 2002, it was reported that 16 criminal charges had been laid against certain Grootvlei prison warders after a special police investigation unit had studied the video made by the "Grootvlei four". See (2002-06-29) Volksblad 1. 
there had been a misunderstanding. ${ }^{38}$ The ongoing uncertainty surrounding Setlai resulted in the press becoming even more suspicious of the motives of the different role players in the affair. For example, the Sowetan stated:

\begin{abstract}
"The contradictory statements from authorities about the position of the corruption-busting head of Grootvlei Prison in Bloemfontein, Tatolo Setlai, are unfortunate and leave a rather sour aftertaste. In fact, viewed from the embattled whistleblower's perspective, these statements could well be interpreted as intimidating instead of reassuring and supportive ... In view of the Government's commitment to cleanse society of anti-social behaviour as well as its attempts to rid the public service of image-imploding corruption, nothing short of a clear and unequivocal support for whistleblowers will instill confidence in authority. The Government needs to move quickly to clear the doubts." 39
\end{abstract}

Another example of the extent to which suspicions had been aroused is to be found in an editorial published in the Afrikaans press on the same day as the extract quoted above appeared in the Sowetan. Volksblad characterised the corruption in the Grootvlei Prison as "net die oortjies van die seekoei" (literally "just the ears of the hippopotamus" - i.e. just the tip of the iceberg). It railed against the possible transfer of Setlai, characterising it as a gross injustice ("skreiende onreg").40

By this point, public concern surrounding this matter had reached such significant levels that it required attention from the highest reaches of government. On 26 June 2002, the Cabinet issued a statement inter alia welcoming the fact that the corruption at Grootvlei Prison had been exposed. Although the government did not necessarily agree with the manner in which the information had been obtained, the Cabinet stated that it was critically important that the evidence be placed before the Jali Commission. ${ }^{41}$

On the same day that the Cabinet issued its statement, it was reported that - at the request of the Democratic Alliance - a snap debate was being held in the National Assembly on the situation in prisons, with specific reference to the Grootvlei Prison. ${ }^{42}$ During the debate, Mrs Pauline Cupido of the Democratic Alliance asked the Minister of Correctional Services, Mr Ben Skosana, to consider installing security cameras in all prisons. Skosana stated that the possibility of establishing an anti-corruption unit for the Department of Correctional Services was being investigated. Members of the Scorpions would possibly form part of this unit. The chairperson of the portfolio committee on correctional services, Mr Ntshiki Mashimby of the African National Congress, asked why the head of the Grootvlei Prison kept a revolver, which had been illegally sold to a prisoner, in his possession for longer than a month. ${ }^{43}$ The National Commissioner of Correctional Services, Linda Mti, appeared before the portfolio committee and admitted that the

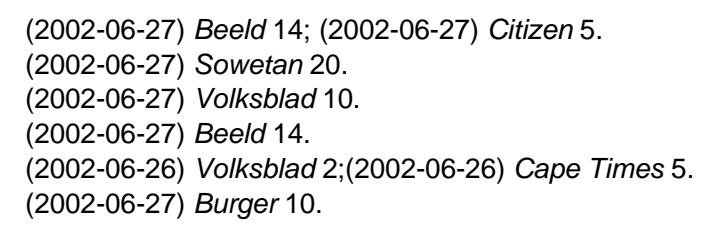


Department of Correctional Services was "beleaguered by the corrupt and criminal activities of a component of staff". ${ }^{44} \mathrm{He}$ told the committee that:

"[t]he legal mandate of DCS remains unachievable while there are staff members in our prisons whose criminal behaviour keeps the wounds of corruption, substance abuse, sexual violence and crime in our prisons festering." 45

The drama in Parliament was mirrored by even more drama at the hearings of the Jali Commission of Inquiry. On the same day that the corruption at Grootvlei was being discussed in Parliament, it was reported that the head of the Grootvlei Emergency Support Unit, Mr Rassie Erasmus, was to be prosecuted departmentally, criminally and civilly - following allegations he had made racist comments about members of the Jali Commission. It was alleged that he had called one of the Commissioners, Esther Steyn, a "teef tussen n klomp kaffers" (a bitch among a group of kaffirs). It was further alleged that he had called Mr Samuel Grobbelaar (one of the "Grootvlei four") a "kafferboetie" (roughly translated as "a kaffir lover"). Judge Thabane Jali ordered that a special investigative unit of the Scorpions should investigate a charge of defamation against Erasmus. ${ }^{46}$

On the same day as the dramatic events described above were being played out, Petrus Sekotoane (one of the "Grootvlei four") gave evidence before the Jali Commission. He told the Commission that not only did warder Ranketse Sephaka sell dagga and mandrax to prisoners, but he also sometimes allowed them into his home within the prison precinct to buy dagga. Sometimes Sephaka's wife sold dagga to prisoners when her husband was not at home. Moosa Mia (another of the "Grootvlei four") told the Commission that warder Johnny Thoabala regularly joined him when he went to buy dagga from, or deliver it to, other prisoners. In doing this, Mia could avoid paying "tollgate fees" of R2 to R5 to other warders manning internal prison gates. Mia also told the Commission that he had drunk brandy with warder TJ Leseba. Warder Mike Ramalefane allegedly ate chicken stolen from the prison kitchen and drank brandy with prisoners. Prisoner William Smith told the Commission that he used to earn approximately R450 a month by selling mandrax for warder Leon Visagie. ${ }^{47}$ Smith told the Commission:

"I sold a packet of dagga inside the prison for R50; R40 of which went to Visagie. The mandrax tablets went for R20 each."48

The following day, 27 June 2002, the long-awaited showdown between Free State Provincial Commissioner for Correctional Services, Willem Damons, and head of the Grootvlei Prison, Tatolo Setlai, took place before the Jali Commission. According to the Sowetan:

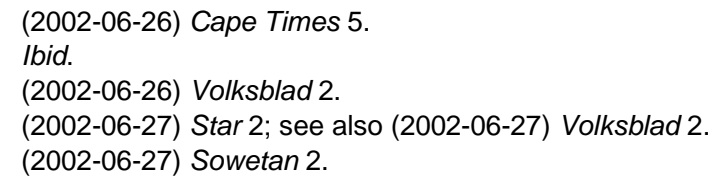


"Setlai maintained that his senior, Free State Correctional Services commissioner Willem Damons, had repeatedly insisted that the damning videotape - allegedly showing corruption in the prison - be destroyed. The beleaguered prison chief was forced to face down Damons before the commission, repeating his assertions that Damons wanted him out of the Department of Correctional Services and had accused him of being a drug dealer ... In a dramatic development in proceedings, Damons vehemently denied telling Setlai that he would be transferred to the Correctional Services' provincial office after the videotape was made public." ${ }^{9}$

According to further press reports, Damons also denied that he had ordered Setlai to destroy the videotape. Setlai, on the other hand, maintained that not only Damons, but also Grootvlei's deputy head, Mrs Moira Dooling, wanted the videotape to be destroyed. According to Setlai, Damons was worried about the videotape and wanted it burned. It was dangerous for Setlai's future and would damage the image of the department and the government, and would scare off investors. According to Setlai, Damons also requested him to influence the prisoners not to cooperate with the Jali Commission. He told the Commission that Damons had that week decided that he (Setlai) was prohibited from setting foot in Grootvlei from 1 July 2002.50 Damons undertook not to investigate, suspend or transfer Setlai - although he told the Commission that he believed that Setlai had contravened practices of good governance. He told the Commission that a national investigation unit was at Grootvlei, at his request, to investigate Setlai's part in the video. ${ }^{51}$ According to a report in the Saturday Star, Advocate Vas Soni accused Damons several times of lying to the Commission and of giving contradictory evidence. According to this report:

"He (Soni) said he would submit to the commission by the end of the day that Damons had been telling one lie after another. 'You lead us into every avenue except the main road. I am lost in your answers', Soni said. He also warned the provincial commissioner that he could lose his job and face charges of defeating the ends of justice if it were found that he had lied to the commission." 52

The drama continued the following day, 28 June 2002, when prisoner Marius Engelbrecht told the Commission that members of the "26" prison gang had put out a "number 1" (i.e., had issued a sentence of death against) on the "Grootvlei four". According to Engelbrecht, who was a "major" in the "26" gang, the four would not be safe in any prison in South Africa, since corrupt warders would be used to get to them:

\footnotetext{
(2002-06-28) Sowetan 3.

(2002-06-28) Volksblad 1.

(2002-06-29) Volksblad 1; (2002-06-29) Saturday Star 2.

52 (2002-06-29) Saturday Star 2. See also (2002-06-30) City Press 9. One newspaper columnist, William Saunderson-Meyer, commented bluntly on the affair as follows: "Correctional Services Commissioner Willem Damons wanted him [Setlai] to destroy the embarrassing video, Police Commissioner Jackie Selebi incorrectly claimed that the miscreants would not be arrested and prosecuted and the initial response of the correctiona services ministry was the threat of a disciplinary inquiry against Setlai to establish whether he had followed 'internal procedures'. What a star-studded cast of morons." (2002-06-29) Independent on Saturday 8.
} 
"They will die in prison, violently at the hands of gang members. There is no safe place in any prison in South Africa for such a prisoner. The saying is that you can run but you cannot hide ... Their number is up. There is no discussion. This is the end. No escape. One way in, one way out."53

With the storm surrounding events at Grootvlei raging in the press, the political and administrative leadership of the Department of Correctional Services went into full "damage limitation" mode. On the same day that Engelbrecht was presenting the dramatic evidence detailed in the previous paragraph to the Jali Commission, the Minister of Correctional Services, Mr Ben Skosana, and the National Commissioner of Correctional Services, Mr Linda Mti, were holding a workshop against corruption at Grootvlei Prison. ${ }^{54}$ Emotions ran high and Mti broke down emotionally and began to cry as he was about to address provincial managers and warders at the workshop. He stated that the anger and heartache of what he had seen on the video was just too much for him. Skosana announced that a campaign was to be launched against all acts and forms of corruption. The reasons for corruption would be established, and strategies would be developed to restrict the spread of corruption..$^{55}$ The Premier of the Free State, Ms Winkie Direko, also addressed the workshop. Speaking to a crowded hall in the prison, she stated that the Free State, South Africa and Africa had been let down by corrupt warders at the prison. These warders had broken the trust placed in them by the national commissioner, Mr Linda Mti, the minister, Mr Ben Skosana, the president, Mr Thabo Mbeki, and the people of South Africa. A furious Ben Skosana stated that South Africans had been knocked off their feet by waves of anger and disbelief after watching the Grootvlei video. The country was in a state of shock, and the damage done to the department would take a very long time to repair. He said that he was not surprised to see the national commissioner overcome by his emotions. $\mathrm{He}$ said that it had been a long hard two weeks since the screening of the video, and he then placed his hand on Mti's shoulder. ${ }^{56}$

\section{The saga continues to smoulder throughout July 2002}

Not everyone was convinced by the display of contrition and emotion described above. On 1 July 2002, columnist Mathatha Tsedu of The Star commented somewhat pessimistically on how he saw the saga surrounding Setlai playing itself out:

"In the nature of how the system operates, Setlai is bound to lose; he is bucking the system, and the system never forgets or forgives. If, right now, with the national spotlight on him and his prison, we are able to witness the kind of harassment he is undergoing, what will happen when the TV lights move away and we all forget about him? It is disappointing that Mti has come across as not too keen to take action against the warders who were caught breaking the law. He has tried to say he was just pointing out that the

53 (2002-06-29) Citizen 6; see also (2002-06-29) Volksblad 1-2.

54 (2002-06-28) Volksblad 1.

55 (2002-06-29) Volksblad 1.

56 (2002-06-29) Volksblad 2. 
evidence might yet be proved to be useless. That is a legitimate concern, but I personally would like to see him defending Setlai against Damons. I would like to see him call Damons in and ask tough questions about the need to destroy the tape, unless this was Mti's instruction. There is a stink coming out of the Free State prison which needs to be allowed to air, and Correctional Services is currently on a path to stem the revelations ... One can only hope that Skosana will continue to provide sound leadership on this matter and that we are not going to wake up one day and find Setlai gone and the warders back on duty." ${ }^{\prime 57}$

A week later, on 7 July 2002, a special report in the Sunday Tribune entitled "Just how deep is the rot?" provided South Africans with a broad overview of what had been going wrong within the penal system as a whole. The report set out the views of Advocate Vas Soni on the reasons for the endemic corruption within many South African prisons. According to the report, Soni believed that the political tensions and battle for power between the old white power structure and new officials appointed after 1994 had contributed greatly to the rot. "Operation Quiet Storm" resulted in prison management being undermined, with POPCRU officials concentrating more on gaining power than on running the prisons. According to Soni:

"The old guard, mostly the whites, sat back and watched the rot fester and the system crumble ... What we saw at Grootvlei happens at all the prisons we have been to. Warders turn a blind eye to criminality. There is a sense of shamelessness among them ... When we saw what was on the video tape it was a case of déjà $v u$. It confirmed what we already knew ... There is nepotism in recruitment. It's like a family business for many. At New Prison in Pietermaritzburg, for instance, a warder had eight relatives working under him. He had the audacity to say that they were the best candidates from more than 2000 applicants." ${ }^{8}$

Two days after the publication of the special report referred to in the previous paragraph, the Setlai saga once again attracted attention in the press. The pessimistic assessment of Setlai's future by newspaper columnist Mathatha Tsedu, in his column of 1 July 2002 - discussed above appeared to be depressingly accurate, when, on 9 July 2002, it was reported that Setlai had been "temporarily" transferred from his post as the head of Grootvlei Prison to the post of chairman of the prison's parole board. This was despite the assurance of Provincial Commissioner Willem Damons to the Jali Commission that Setlai would not be transferred or moved. According to the Sowetan:

"The transfer has been widely viewed as part of an attempted cover-up after Setlai allowed four long-term prisoners to record alleged acts of corruption by up to 22 Grootvlei warders and inmates on videotape."

Setlai submitted a complaint to the Jali Commission to the effect that he had been victimised because of his struggle against corruption. ${ }^{60}$ The South African Police Union issued a statement to the effect that moving Setlai out

\footnotetext{
(2002-07-01) Star 8.

(2002-07-07) Sunday Tribune 4.

(2002-07-09) Sowetan 3.

60 (2002-07-09) Beeld 2.
} 
of his post sent a message that whistleblowers were not protected within the Department of Correctional Services. The Union called on the Minister of Correctional Services, Mr Ben Skosana, and the Jali Commission, to come to Setlai's rescue. ${ }^{61}$ The fact that Setlai was being deliberately targeted seemed to be borne out by evidence presented to the Jali Commission a few days later, on 14 July 2002, by Grootvlei prisoner Kenneth Kunene. Kunene alleged that a group of warders belonging to POPCRU had formulated a plot to get rid of Setlai. In terms of the plan, unlawful items like dagga would be planted in the cupboards of Setlai's monitors - to show him in a bad light. Setlai would be worked out of the system. It was reported that Setlai was reconsidering his charge of victimisation against the Department of Correctional Services, after being removed from his post as head of the Grootvlei prison. ${ }^{62}$

In addition to the Setlai saga, the South African press continued to give wide coverage to other shocking revelations made by witnesses who appeared before the Jali Commission. On 14 July 2002, one of the "Grootvlei Four", Gayton McKenzie, told the Commission that Grootvlei warder FV Mostert ran a shebeen in the prison, from which the warder earned more than R9 000 per month. Up to 20 bottles of brandy were sold to prisoners per week at a price of R200 or R300 per bottle. McKenzie alleged that liquor was smuggled into the prison hidden in sand or cement - or in paint tins. McKenzie told the Commission that pornographic films were so freely available in the prison that one did not even have to pay to watch them. He told the Commission that he had seen all the newest pornographic films on the market. Evidence was led before the Commission to the effect that warder Frans Molejane, who had been caught with 23 bags of dagga in the Virginia prison, had been reassigned to Grootvlei Prison by Damons. It was alleged that Molejane sold food, brandy, dagga and ecstasy in the prison. ${ }^{63}$ McKenzie told the Commission that the "Grootvlei Four" had been so badly victimised as a result of the video, that at one point they had decided to cease cooperating with the Commission. ${ }^{64}$ Two days later, on 16 July 2002, McKenzie told the Commission that the four had been dismissed from their positions as monitors without reason, and were locked in their cells for 23 hours per day. He said that their cells were searched daily and that they had been forced to live on bread and cooldrink for the past 10 days, since they were afraid to eat meat from the prison kitchen. He alleged that an attempt had been made to poison Samuel Grobbelaar, one of the "Grootvlei Four", with "Two Steps". 65

The Setlai saga returned to the news on 17 July 2002, when the acting head of the Grootvlei Prison, Langa Bikane, gave evidence before the Jali Commission. He admitted that Setlai's transfer to the parole board was unfair. Bikane had signed both the letter informing Setlai of his suspension in May, as well as the letter informing him of his transfer to the parole board in

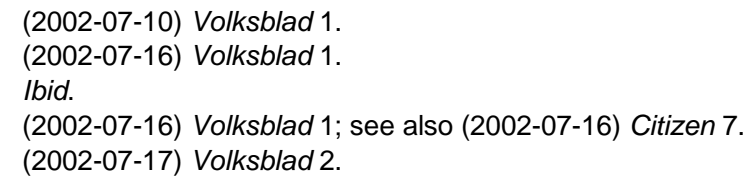


July. Bikane told the Commission that he did not want to suspend Setlai in May, but had to sign the letter informing Setlai of his suspension, as Provincial Commissioner Damons and his advisory team had decided to suspend Setlai. He had also had no choice but to sign the letter from the task team in July informing Setlai that he was being transferred from his position as head of the Grootvlei Prison to the Parole Board in Bloemfontein. ${ }^{66}$ The following day it was reported that Setlai intended to launch an urgent application in the Free State High Court to be allowed to remain in his position as head of the Grootvlei Prison. ${ }^{67}$

On 19 July 2002, heart-rending evidence was presented to the Jali Commission by a 20 -year-old juvenile inmate of Grootvlei Prison. He alleged that he had been sodomised 11 times in the prison by a warder and other prisoners. The juvenile alleged that on his second day in Grootvlei Prison, a prisoner sodomised him for the first time. Within his first week in the prison, a further two prisoners sodomised him. He sought help from a warder, Sam Mohanoe, who proceeded to sodomise him as well. He alleged that he was sodomised seven times by the warder in the warder's office and in a storeroom. The juvenile was eventually detained in a single cell for his own safety, but was allegedly "put on auction" and "sold" by a warder to another prisoner for sex. After this, he twice tried to commit suicide. Advocate Vas Soni stated that it was "a sad day for the prison system in South Africa" and he apologised to the prisoner "on behalf of all decent human beings". ${ }^{68}$

A few days later, on 23 July 2002, one of the Grootvlei four, Petrus Sekutoane, told the Commission that one of the warders regularly left a 25litre tin full of dagga in his cell overnight. Sekutoane would then sell the dagga to other inmates. The cost of a tin of dagga was R1 000, and this was sold to inmates for R2 500. Sekutoane alleged that profits from the sale of dagga had been deposited into his bank account by the warder who had supplied him with the drugs. ${ }^{69}$ On the same day, further heart-rending evidence was presented to the Commission about the frequent occurrence of prison rape. Grootvlei prisoner Wilson Mohodi told the Jali Commission that a Grootvlei warder known as "Daddy" sodomised young male prisoners in his office on a daily basis. Mohodi told the Commission that the warder, a certain Sam Mohanoe, had been sodomising juveniles since 1985. Mohanoe was facing criminal charges for allegedly sodomising a 20-year-old prisoner eight times. According to Mohodi, he and Mohanoe sometimes took turns to sodomise juveniles in Mohanoe's office. Mohodi also told the Commission that he sometimes supplied Mohanoe with a young man in return for cannabis. Mohanoe would reward the juveniles with cannabis, Vaseline and toiletries in a plastic bag. Sometimes Mohodi paid a warder R20 to bring a juvenile to his cell for the weekend. Mohanoe's legal representative denied that his client had sodomised juvenile prisoners. ${ }^{70}$ In further evidence, a 20year-old Grootvlei prisoner testified before the Commission that he was

(2002-07-18) Citizen 7; (2002-07-18) Volksblad 2; (2002-07-18) Afrikaner 3.

(2002-07-18) Volksblad 2; (2002-07-18) Afrikaner 3.

(2002-07-21) Sunday Independent 5; (2002-07-20) Beeld 4.

(2002-07-24) Volksblad 2.

$70 \quad$ (2002-07-23) Volksblad 1. 
promised All Star running shoes and food by an older prisoner - in return for sex. He testified that he had been repeatedly sodomised by warders and older prisoners. ${ }^{71}$

Finally, to end off this overview of the public discourse surrounding events at Grootvlei Prison in 2002, a brief comment on the fate of Tatolo Setlai is made. On 24 July 2002, it was reported that Setlai had been transferred back into his post as head of the Grootvlei Prison, presumably as a result of legal pressure he had brought to bear. ${ }^{72}$ Unfortunately, this was not to last. On 16 January 2003, Setlai appeared in the regional court on charges of corruption. He claimed that he was framed and that the charges were a "payback" by officials of the department, for what he had told the Jali Commission.

It is clear from the above that any ordinary South African who bothered to read the newspapers during June and July 2002 would have been under no illusions as to the seriousness of the problems confronting the Department of Correctional Services in relation to corruption. Any illusions as to the supremacy of human rights in the post-apartheid period was likely to have been dashed. In concluding this sub-section, it is worth noting that the disturbing picture painted in the press was confirmed in the final report of the Commission. ${ }^{73}$ This report reflected a government department on the brink of collapse, riddled with corruption and beset by criminality and other forms of malpractice. ${ }^{74}$

(2003-07-24) Star 3; (2002-07-24) Volksblad 2.

(2002-07-24) Volksblad 1; (2003-07-24) Star 3.

The Jali Commission furnished its Final Report to the President in December 2005.

74 The Final Report had been preceded by a series of Interim Reports, which the Commission explained were necessary because the Department of Correctional Services was "experiencing a total breakdown in the disciplinary system, which required recommendations for immediate intervention" (Jali Commission Report Vol 1 16). The Commission noted that the interim reports dealt with "illegal drug dealing, medical aid fraud, favouritism in appointments, extortion, unlawful financial transactions with prisoners, fraudulent matric certificates, unlawful visits, theft, fraud, assault of prisoners, irregular appointments, irregular transfers and parole transgressions amongst other things" (Jali Commission Report Vol 1 16). It went on to deliver the following damning indictment of the institutional culture within the Department: "The most noticeable feature of the institutional culture the Commission observed was that corruption and maladministration were rife in most of the Management Areas investigated. There is a large group of employees within such Management Areas who featured in almost all the incidents of corruption and maladministration and who are predominantly driven by greed and the need to make easy money. This became apparent in the nature of the corruption that is endemic within the Department ... The investigations also revealed that many employees consciously and systematically disregard Departmental rules and regulations. The failure or refusal to comply with rules and regulations of the Department became apparent in the manner in which these employees consciously and deliberately flouted regulations relating to security, searching of members, searching of visitors, visitation rights, procurement of goods for the prisoners, the relationship between prisoners and warders, recruitment and appointments, promotions, merit awards, transfer, parole, disclosure of private work, treatment of prisoners, use of State assets and others. This appeared to be done with impunity in that there was little evidence of disciplinary action being taken against the transgressors" (Jali Commission Report Vol 117). 


\section{CONCLUSION}

The Jali Commission of Inquiry appears only to have been moderately successful in bringing about direct improvements to the South African penal system over the medium to long term. In assessing the condition of South Africa's prisons in 2016, a decade after the conclusion of the Commission, Lukas Muntingh states:

"Ten years after the Jali Commission released its report, the DCS remains beset by the same problems as those the commission was established to address: overcrowding, corruption, impunity, rights violations and services that do not reach sufficient numbers of prisoners and leave much to be desired with regard to impact. All indications are that there have been significant improvements in the DCS, especially regarding corruption and maladministration, but that there is plenty that remains unacceptably dysfunctional."75

Although the investigation conducted by the Jali Commission of Inquiry did not result in the resolution of all the many problems that were identified within the penal system, it is clear that the overall value of the Commission cannot be judged on this fact alone. This article has focused on the impact of extensive newspaper reporting during the hearings of the Commission on the public at large - in particular on public perceptions regarding issues of corruption. Muntingh's observation that there were "significant improvements in the DCS, especially regarding corruption and maladministration" is clearly significant in this regard. ${ }^{76}$ Speculating about the value of changing public perceptions on issues such as corruption is bound to be somewhat imprecise. Nevertheless, it is submitted that public perceptions are extremely important when it comes to defeating deeply rooted and complex social ills. Furthermore, it is submitted that there is sense to be made in relation to the manner in which public perceptions are constructed and shaped. Furthermore, as discussed below, it is contended that such perceptions may serve to render a society based upon principles of liberal constitutional democracy more resilient in the face of major challenges, such as widespread corruption.

As far as public perceptions are concerned, it is submitted that in the aftermath of South Africa's first democratic election at the start of the postapartheid era, an overwhelming majority of citizens dreamed of a future characterised by tolerance and respect for the basic human rights of each of the country's inhabitants..$^{77}$ It is difficult to say precisely when these dreams began to fade, as corruption took hold in different areas of public life. ${ }^{78}$ It is clear, however, that extensive media reporting on the hearings of the Jali Commission of Inquiry - traced in this article - constitute an important early

75 Muntingh Ten Years After the Jali Commission: Assessing the State of South Africa's Prisons 201658 SACQ 42.

76 Ibid.

77 South Africa's first democratic election was held on 27 April 1994.

78 Of course, rampant corruption in South Africa pre-dates 1994. Corruption was a defining feature of the apartheid system. See, for e.g., Van Vuuren Apartheid, Guns and Money (2017). See also Van Vuuren Apartheid Grand Corruption: Assessing the Scale of Crimes of Profit in South Africa From 1976 to 1994 (2006). 
milestone along the road that South Africans have travelled towards increasing disillusionment with the state of corruption within important institutions of state. Although the Jali Commission failed to root out corruption completely within the South African penal system, or (at a more general level) to prevent the major corruption scandals that were to characterise the presidency of Jacob Zuma, it is submitted that this commission cannot be written off as a waste of taxpayers' money. It may be argued, perhaps, that the present outrage of South Africans at the manner in which corruption has brought the country to its knees - together with a determination among many finally to confront and defeat this scourge - was first "primed" by the narrative that emerged from the hearings of the Jali Commission.

The Jali Commission was able to place a fairly discrete set of corrupt practices under a judicial microscope, with sufficient resources to conduct a thorough and open analysis in a legally rigorous manner. The public narrative that emerged from the hearings of the Commission, provided the public with a wealth of minute and often banal detail as to the manner in which corruption was able to establish a foothold and flourish in South Africa's "post-liberation setting". It became clear that, in an environment characterised by political turbulence and economic flux, avenues for corruption that may otherwise have been closed, were opened up and exploited by ruthless individuals. The manner in which corruption was able to "hollow out" an institution from the inside, despite the existence of legal and constitutional safeguards, was revealed for all to see. In the extensive reporting on the hearings of the Commission, the South African public was able to experience something of the "smell and feel" of the corruption that had started to take hold of certain institutions of state during the early years of the post-apartheid period. It is the contention of this article that the "up close and personal" understanding of the mechanics and corrosive effects of corruption provided by the Jali Commission - albeit in relation to a single institution of state - may be regarded as an important building block of current public perceptions on the general issue of corruption.

Returning, finally, to the precarious time at which these words are being written, it is the contention of this article that South Africa's very survival as a liberal constitutional democracy depends upon the determination of the public at large to root out corruption. It is submitted that Cathleen Powell's observation (referred to in the introduction to Part 1 of this article), that commissions of inquiry may serve to ensure public "buy-in for important processes of change and renewal", is absolutely correct. ${ }^{79}$ So too is her

79 Powell "South Africa's Commissions of Inquiry: What Good Can They Do?" The Conversation" (8 November 2018) https://theconversation.com/south-africas-commissionsof-inquiry-what-good-can-they-do-106558 (accessed 2021-05-06). Powell's rejection of the common misconception that the appointment of a commission of inquiry automatically leads to a reduction in public concern about the issue being investigated, receives solid support from Raanan Sulitzeanu-Kenan. Sulitzeanu-Kenan refutes the "common claim" that "the appointment of an inquiry acts to reduce the level of public interest in the affair [which led to such appointment]", stating that "despite the prevalence of this claim, no empirical support was found for any mitigating effect of inquiry appointment on media salience in recent 
observation that the "most important work of the Zondo and Nugent Commissions might be done before their formal function - the submission of their reports - is completed." 80 While clearly not a panacea, the proceedings of a public commission of inquiry within a liberal constitutional democracy when properly handled and working in tandem with a free and vibrant press - may serve to educate and inform the public, creating an important bulwark against corrupt forces that seek to subvert that democracy. This is particularly the case in times of existential crisis, such as the present threat posed by corruption and "state capture" to South Africa's constitutional democracy. Such commissions of inquiry are worth every cent of their cost.

studies." See Sulitzeanu-Kenan "Reflection in the Shadow of Blame: When Do Politicians Appoint Commissions of Inquiry?" 2010 40(3) BJPS 617.

80 Powell https://theconversation.com/south-africas-commissions-of-inquiry-what-good-canthey-do-106558. 